\author{
Małgorzata Klaudia Kozlowska \\ magister, adwokat \\ Doktorantka w Zakładzie Prawa \\ Administracyjnego Wydziału \\ Prawa, Administracji i Ekonomii \\ Uniwersytetu Wrocławskiego \\ m.kozlowska86@wp.pl
}

DOI: $10.35117 / A \_E N G \_17 \_01 \_02$

\title{
Animal traffic on the road. Limitation in the traffic. Legal regime related to the traffic organisation.
}

\begin{abstract}
Becoming increasingly rare is the picture of the animal traffic on the public road. By this traffic it is understood animal prodding and animal riding. Even though this effect decreases from one year to another legislator very strictly determined rules that apply to this traffic. The author of this article describes in it not only general rules that determine the animal traffic on the roads but also analyses detailed regulations that concern animal prodding and animal riding. This article pays attention also to prohibitions that apply to animal traffic and related to them violations - offence and criminal liability. At the end author points out to problems in the definition layer related to animal traffic on the road and formulates postulates de lege lata.
\end{abstract}

Keywords: Animal traffic on the road; Road dedicated for animal prodding; Animal prodding;

\section{Legal regime for the animal traffic on public roads}

In the age of modern civilization movements, the animal traffic along the way through which, according to Article 35 (1) of the Law on Road Traffic [hereafter referred to as the act] [11] should be understood as animal prodding and riding, is an increasingly rare view on Polish roads. We usually do not come across this phenomenon near the agglomeration of big cities, but it is more common in rural areas where agriculture is still the main source of subsistence for their inhabitants. Although the animal traffic on the road is decreasing year by year, what is a consequence of urban development and a decrease in the number of head-count species [1], among other things, as a result of the decline in profitability of agricultural production, it is still a statutory issue. The animal traffic was regulated only in the aforementioned act.

The legislator has dedicated only 3 articles in chapter 4 of the Act, and yet this traffic is a subject to strict rules, the violation of which may result in the offense referred to in art. 97 Code of Misconduct [12]. One should not lose sight of the fact that the animal traffic on the road is part of a broadly understood road traffic, the safety of which is one of the priorities of the legislator expressed on the basis of the provisions of the law.

\section{Animal traffic should take place along the road}

In the Article 35 (1) of the Law it is explicitly stated that animal riding or prodding should be carried out firstly on the road dedicated for running the animals. Unfortunately, in the act, there is no point in looking for the definitions of that path, which means that you should search for the non-statutory designatum of the mentioned name. In the opinion of R. A. Stefański, the road intended for animal traffic should be understood as "roads where animals are mainly driven from pastoral areas outside the village [7]". The above definition does not, however, dispel doubts as to what is meant by a specially designed road for the animal traffic. 
Referring to the provisions included in Chapter 4 of the Law entitled "Animal traffic", a partial negative definition of the road to animal movement can be derived. To be considered, and contrario to the wording of art. 35, 36 and 37 of the Act, that it is not a roadside, a road consisting of a road used for vehicular traffic, and in particular motorways, express roads and roads marked with the B-8 sign, i.e. no entry for vehicles with animal traction. In the event of road for animal traffic absence, according to the norm in Article 35 (1) of the Law, animal riding or prodding may take place at the roadside, i.e. a part of a road adjacent to a roadway which may be intended for pedestrian traffic or certain vehicles, vehicle stops, animal riding or prodding. Only the lack of roadside makes that the animal traffic can take place on the road. To summarize, it must be stated that the possibility of entering animals onto a roadway, i.e. a part of a road intended exclusively for vehicular traffic, is a derogation from the rule and can only take place if the animal traffic cannot be carried out on the road to that intended or after the roadside due to lack of it or temporary inability to use it. At the same time, the Act, due to the need to ensure road safety, forbids the taking of more than the right half of the roadway or the road for pedestrians or bicycles [10].

\section{Not every road for animals}

The current provisions of the Act, although allow the animal traffic on the road, but due to its specificity, and in particular the obstacles that may cause, the legislator pointed out enumerating in enumerated manner - types of roads on which this movement is strictly forbidden. This folder is a closed folder.

Thereby riding and prodding the animals are always prohibited "on the road marked with signs with the number of international road (road E-16), and the way in which driving is restricted sled, and therefore: freeway, expressway, as well as on the road marked with the B8 sign prohibiting the entry of vehicles with animal traction, which denotes the ban on both vehicles with animal traction as well as riders and drovers [8]".

\section{Regulations for the animal traffic along the road}

The law strictly regulates how and under what conditions the animal traffic along the road should be done and who is obliged to notify the movement.

Directives on this matter are specified directly in the law or in the provisions to which the law refers expressly and requires the appropriate application thereof or in general traffic rules. Consequently, acts contrary to statutory injunctions or normative prohibitions are sanctioned.

In the case of prodding, the person responsible for the proper organization of their movement is the drover and in the case of riding - the rider. These people are obliged to comply with the provisions not only on the movement of animals but also on the regulations on the movement of motor vehicles [3]. Both the drover and the rider as defined in Art. 2 point 20 of the Act, they were - as well as the managers of the vehicles - recognized as the leaders. Unlike drivers of motor vehicles, however, neither the drover nor the rider need to have any permissions in this field. [10]. At the same time, the law introduces a censorship of the age for animal riders and drovers. A person driving on a hard road must be at least 17 years of age (see Article 36, paragraph 1, point 5 of the Act) and prodding animals - 13 years (see Article 37, paragraph 4, paragraph 2 of the Act). Article 2 (2) of the Act defines the concept of a hard road under which a road with a bituminous, concrete, cobblestone, clinker or pavement surface roadway and concrete or stone-concrete slabs should be understood if the road surface exceeds $20 \mathrm{~m}$. Therefore, no other age limit is imposed on other roads than hard roads, for example on dirt roads, towards riders and drovers. According to Article 35 (2) of the Law on Driving and Prodding Animals on a Hard Way is applicable, in addition to the 
regulations regulating the direct animal traffic (Articles 35 to 37 of the Act). 34 (1) and (2) governing the movement of vehicles with animal traction and traffic rules.

As in the case of sled animals, the animals moving along the hard path should be unobtrusive, physically fit and self-directed [4]. At the same time, the drover who rides the animals or is riding on the road is a subject to the relevant traffic regulations. Due to the specifics of animal traffic, not all vehicle traffic regulations will apply to people who are prodding or riding on the road. It is understood that towards these specific group, regulations concerning speed and braking and towing will not be applied. However, it is worth pointing out W. Kotowski's view that had noticed that speed and braking rules may be applied to riders because "the horse under certain conditions has the possibility of exceeding speed [3]".

Both riders and drovers are obliged to comply with the principle of right-sided traffic (Article 16, paragraph 1 of the Act), moving as close as possible to the right side of the road (Article 16, paragraph 4 of the Act), adherence to the principles of: entering the traffic (Article 17, pragraph 1 and 2 of the Act), changing lanes and driving direction (Article 22 of the Act), overtaking (Article 23, paragraph 1, points 1 and 2 of the Act and Article 24 of the Act), rules related to crossing the two directions of traffic (Article 25 of the Act), passage through the pedestrian crossing (Article 26 of the Act) or passing through a railway crossing (Article 28 of the Act) [9]. Furthermore, the regulators should take care of the road cleanliness the animals move on (Article 45 (1) (10) of the a contrario).

\section{Detailed rules for animal riding and prodding}

In addition to the general principles for each animal traffic, the legislator in the subsequent articles of Chapter 4 decided to introduce specific rules for the animal riding and prodding, which was dictated by the specific differences associated with each variation of this movement.

How animals should be driven properly along the road provides Art. 37 of the Act. This provision contains a complete list of orders and prohibitions related to the animal traffic both on the roadside and on the roadway. At the same time, it should be noted that the legislator in the article referred to differently regulated the animal prodding in the herd and singly. Animals in the herd may be guided only under appropriate supervision. By contrast, a single animal can only be carried on tether. Animals may also be carried loose in a sled vehicle on the right, but not exceeding 2 animals.

Taking into consideration the fact that drover supervises animals, the Act imposes a number of specific obligations, since "the drover must do so in such a way as not to endanger the safety of the traffic and not harm anyone." [9]". Therefore, the drover is obliged to walk on the left side of the animals he prods to be able to control them and to prevent the animals from leaving the right side of the road, and during a period of inadequate visibility he is obliged to carry a flashlight with white light visible from a distance at least 150 meters.

On the other hand, when it comes to riders, in order to ensure road safety, they should comply with the prohibitions described in Art. 36 of the Act. According to its objectives the rider should always ride a bristled animal. This obligation applies both to the roadside and to the roadway. This is essential for road safety, for driving without a bridle may hinder or even prevent animal guidance [6]. In addition, it is forbidden to ride side by side with another participant on the roadway, "which means that two riders are allowed to drive next to each other on the roadside [5]"

\section{Prohibitions in the animal traffic}

Prohibitions relating to riding and prodding animal concern not only the type of road on which movement cannot be done, but also affect other equally important issues that have an impact on ensuring road safety. In any situation it is forbidden to ride on a hard road during 
periods of insufficient visibility, "which means that the ban is valid from dusk to dawn, and also in conditions of reduced air transparency from dawn to dusk caused by, for example, precipitation [5]". In the case of animal prodding, it is forbidden to prod the animals across the road in an invisible place at a sufficient distance, to keep the animals on the roadway and to occupy more than half of the road or pedestrian/ bicycle paths.

The law also includes prohibitions on the riders and the drovers themselves. Except stated outright in the regulations prohibition on animal riding and prodding on the hard road to a person who has not reached the age referred to in the provisions of art. 36 and 37 of the Act, in relation to those guiding, the legislator introduced further restrictions. Article 45, paragraph 1, point 1 of the Law prohibits animal and prodding in the state of intoxication, in the state after the use of alcohol or alcohol-like remedies. Thus, the legislature rightly included the ban on all the supervisors, including animal riders and drovers, since the number of crimes and misdemeanors involving alcoholics is still high.

\section{Legal offense related to the animal traffic}

Road traffic issues have been regulated in detail by the standards containing the prohibitions and prohibitions addressed to its participants. Nevertheless, the Act does not regulate the appropriate authorities giving permission to sanction behaviors incompatible with the legal norm. The provisions penalizing activities contrary to the disposition of the norm expressed on the basis of that law should be sought in the Offences Code.

The rider or drover who has committed a breach of the special rules on the animal traffic (Articles 35 to 37 of the Act) or the general rules governing road traffic, which refer to the animal movement supervisors are subject, in accordance with the sanction laid down in Art. 97 Code of Misdemeanors, fine of up to 3,000 zlotys or a reprimand.

The same punishment is subject animal supervisor in the state after the use of alcohol. However, if a drover or rider under the influence of alcohol bring the risk of road traffic on public roads, then the legal classification of the offense enrolled in Art. $86 \S 2$ of the Code of Misdemeanors, which carries a prison sentence, imprisonment or a fine.

By contrast, the supervisor, who leads to the public road contamination should be punished with a fine of up to PLN 1,500 or a reprimand, as inArt. 91 of the Code of Misdemeanors.

The animal traffic issue, however succinctly regulated by the law, is a broad subject, generating, especially in the definition layer, many doubts.

The lack of specific definitions makes it sometimes difficult to assess whether the animal traffic is done properly.

The Road Traffic Act does not provide a definition of the road intended for the animal traffic, as well as there is no point in seeking designatas of that name in further provisions of that legislation. It should be noted that only in the absence of this road, the supervisor may use the roadside, and in the absence of it or inaccessibility - the roadway.

Likewise, under national legislation there is no definition of a not overmodest animal that want to be guided. This name, depending on who is interpreting the norm, can have a very narrow or very wide circle of designatas, which allows instrumental use of the law.

Finally, the lapidary and technical regulation of the animal traffic, with reference to the rules that prima facie concern the drivers of a motor vehicles, makes it much more difficult to supervise the movement and to impose sanctions on behavior that threatens safety.

Consequently, although the animal traffic from year to year will become an increasingly marginal phenomenon, the author's view would be to define the concept of a road dedicated for prodding and to indicate the categories of not overmodest animals whose movement along the road and prodding are acceptable, so that the law was unambiguous and 
did not leave much possibilities for interpretation, which would enable effective supervision and control over its observance and the limited possibility of instrumental use of it..

In addition, allowing people with limited legal capacity, i.e. people over the age of 13 but who not reach the age of majority, to supervise the movement of animals along the hard road (the drover must be at least 13 years old and a rider 17 years old) is a serious concern for the author. „A person with limited legal capacity may, in accordance with Art. 426 of the Civil Code, be liable for damages caused (the tortious ability), if it can be in this case the blame when he/she was understanding the consequences of his/her behavior [2]". Therefore, when prodded animals inflict damage to another participant of traffic (e.g. frightened animals damage the motor vehicle), the victim will be obliged to issue a claim for damages against a juvenile offender, because of his private fortune, will not be able to cover caused by supervised animals damage. Thus, it would be reasonable to raise the age in the census compared to people entitled to prodding the animals and riding on the hard road from 18 years old, possibly requiring owners of animals to buy special insurance that would cover the potential damage associated with their movement along this road.

\section{Source materials:}

[1] Główny Urząd Statystyczny, Zwierzęta Gospodarskie w 2013 r. Informacje i Opracowania Statystyczne, Zakład Wydawnictw Statystycznych, Warszawa 2014, s. 41- 62.

[2] Kidyba A., Kodeks cywilny. Komentarz. Tom I. Część ogólna, wyd. II, WKP 2012

[3] Kotowski W., Komentarz do art. 35, Prawo o ruchu drogowym. Komentarz, wyd. III, ABC 2011, s. 463.

[4] Malinowski Ł., Komentarz do art. 35, Prawo o ruchu drogowym. Komentarz, LexisNexis 2012.

[5] Malinowski Ł., Komentarz do art. 36, Prawo o ruchu drogowym. Komentarz, LexisNexis 2012.

[6] Musielak K., Koń i jeździec w ruchu drogowym, Equista.pl, 16.12.2015 r. [http://equista.pl/editorial/943/kon-i-jezdziec-w-ruchu-drogowym stan na dzień 03.01.2016 r.]

[7] Stefański R. A, Komentarz do art. 35, Prawo o ruchu drogowym. Komentarz, wyd. III, LEX 2008, s. 322.

[8] Stefański R. A, Komentarz do art. 36, Prawo o ruchu drogowym. Komentarz, wyd. III, LEX 2008, s. 323.

[9] Stefański R. A, Komentarz do art. 37, Prawo o ruchu drogowym. Komentarz, wyd. III, LEX 2008, s. 324- 325.

[10] Tuliszka J., Ruch pieszych, zwierząt i pojazdów na drodze, Biblioteka Policjanta Prewencji, Słupsk 2011, s. 35.

[11] Ustawa z dnia 20 czerwca 1997 r. Prawo o ruchu drogowym (Dz.U.2012.1137 j.t.).

[12] Ustawa z dnia 20 maja 1971 r. Kodeks wykroczeń (Dz.U.2015.1094 j.t.). 